\title{
Factors Related to Chronic Energy Deficiency among Pregnant Women
}

\author{
Shinta Novelia ${ }^{1}$, Rukmaini², Ema Annisa ${ }^{3}$
}

1,2,3Midwifery Department, Universitas Nasional Jakarta, shinta.novelia@civitas.unas.ac.id (Corresponding Author)

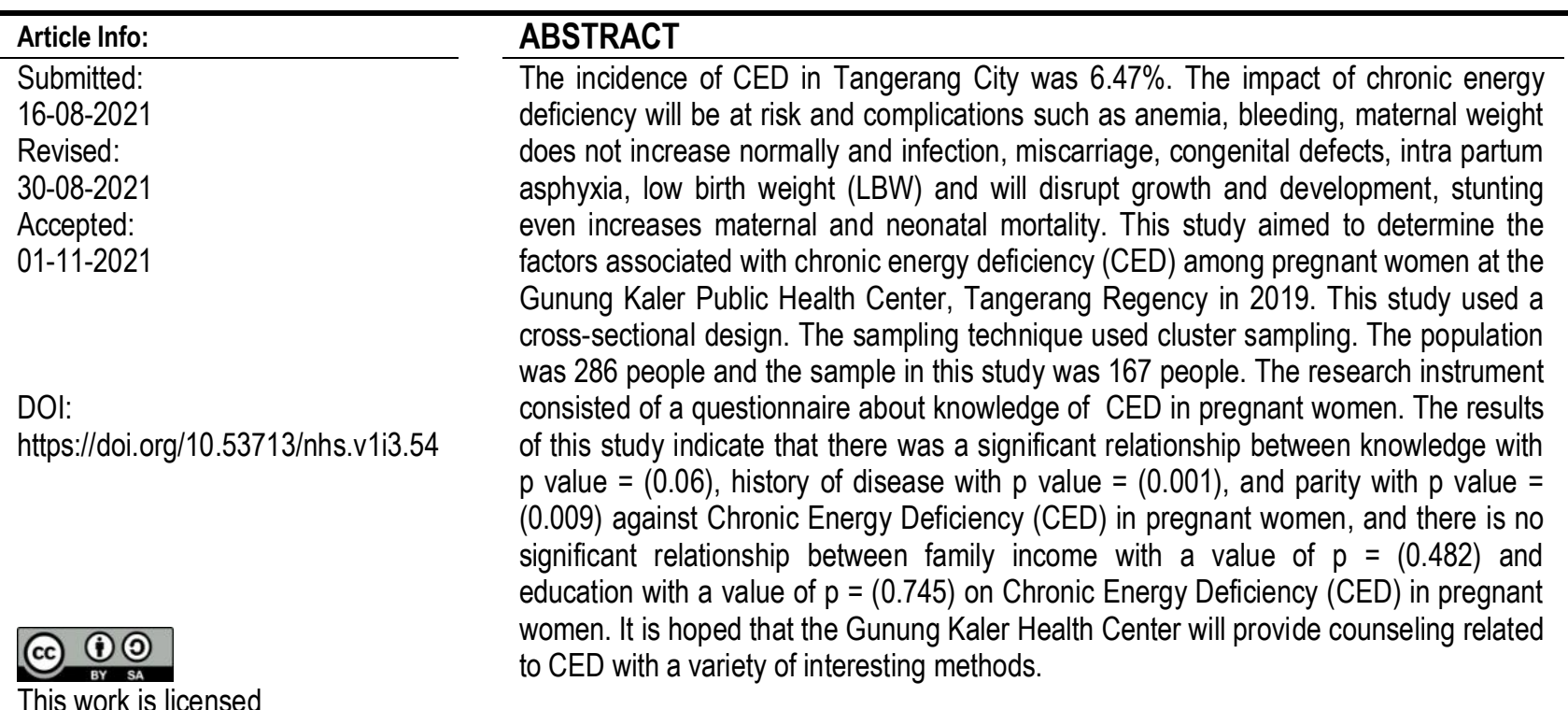

Keywords: CED; knowledge; medical history; parity; education; family income

\section{INTRODUCTION}

According to the Indonesian Demographic and Health Survey (IDHS) in 2012, the maternal mortality rate in Indonesia was still high at 359 per 100,000 live births compared to 2007 the maternal mortality rate was 228 per 100,000 live births (Ministry of Health, 2014). According to the Minister of Health No. 97 of 2015 The SDGs target in 2030 reduces the maternal mortality rate to below 70 per 100,000 live births. The number of maternal deaths in Banten province in 2015 reached 264 cases. Maternal mortality is due to bleeding was 76\%, hypertension in pregnancy was $68 \%$, infection was $25 \%$, bleeding disorders was $28 \%$, metabolic disorders was $1 \%$ and others was $66 \%$ (Banten Provincial Health Office, 2016). The number of maternal deaths in Tangerang Regency in 2017 was 43 cases and there was a decrease compared to 2016 this is due to the increasing number of health centers capable of PONED, which was 27 in 2015, 36 in 2016 and 40 in 2017.

The basic data as material for determining the percentage of pregnant women with CED is obtained from the results of the Basic Health Research (Riskesdas) in 2013. With this target set, it is hoped that the percentage of pregnant women with CED will not exceed the target each year. Data for pregnant women with CED was obtained by comparing the number of pregnant women whose upper arm circumference (LILA) was measured using a LILA tape (measured result was less than $23.5 \mathrm{~cm}$ ) divided by the number of pregnant women whose LILA was measured multiplied by $100 \%$. In 2015 , based on the results of the 2015 nutritional status monitoring survey (PSG), the figure was $13.3 \%$, where this figure was below the target or as expected (Kemenkes RI, 2016).

Chronic energy deficiency (CED) is a condition where the mother suffers from a chronic (chronic) calorie and protein deficiency (malnutrition) which results in health problems in women of reproductive age and in pregnant women (Simbolon et al., 2018). The impact of chronic energy deficiency will be at risk and complications such as anemia, bleeding, maternal weight does not increase normally and infection, miscarriage, congenital defects, intra partum asphyxia, low birth weight (LBW) and will disrupt growth and developmen, stunting even increases maternal and neonatal mortality (Simbolon et al., 2018).

Chronic energy deficiency in pregnant women is caused by 2 factors, namely direct and indirect factors (Simbolon et al., 2018). The direct causes are inadequate nutritional consumption and disease. Meanwhile, indirect factors for 
pregnant women with CED are insufficient food supply, inadequate parenting and environmental health and inadequate health services. All factors are directly and indirectly influenced by the lack of empowerment of women, families and human resources as the main problem, while the basic problem is the economic, political, and social crisis. Another study found the factors related to CED are family income, education, maternal age, parity, food consumption patterns, history of infectious diseases (Petrika, Hadi \& Nurdiati, 2016; Rahmi 2016). According to research conducted by Laila Rahmi (2016) found that there was a relationship between parity, age, family income and pregnancy distance with Chronic Energy Deficiency in pregnant women at the Padang Belimbing Health Center with a population of 1,308 pregnant women, a sample of 42 pregnant women with Consecutive Sampling. From the results of the initial survey conducted on May 22 in Gunung Kaler Health Centre Tangerang Regency in 2019; out of 10 pregnant women, 2 people experienced Chronic Energy Deficiency. The purpose of this study was to determine factors related to Chronic Energy deficiiency among pregnant women at Gunung Kaler Health Center Tangerang Regency in 2019.

\section{METHOD}

This study used a cross-sectional study. The population was the total number of pregnant women in the work area of the Gunung Kaler Public Health Center in March - May 2019 which was 286 people. The sample was 167 pregnant women which calculated by Slovin Formula. This research was conducted at the working area of the Gunung Kaler Public Health Center, Tangerang Regency and was carried out at the "Posyandu" in the village. This research was conducted on 21-27 June 2019.

\section{RESULT}

\section{Univariate Analysis}

Table 1. The univariate analysis of all variable

\begin{tabular}{lcc}
\hline \multicolumn{1}{c}{ Variable } & $\mathrm{n}$ & $\%$ \\
\hline CED & 44 & \\
CED & 123 & 26.3 \\
NOT CED & & 73.7 \\
\hline Knowledge & 82 & 49.1 \\
Good & 85 & 50.9 \\
$\quad$ Poor & 9 & \\
\hline Disease history & 158 & 5.4 \\
Yes & & 94.6 \\
No & 29 & \\
\hline Parity & 131 & 17.4 \\
Primipara & 7 & 78.4 \\
Multipara & & 4.2 \\
Grande multipara & 10 & 6 \\
\hline Family income & 157 & 94 \\
High & & \\
Low & 5 & 3 \\
\hline Education & 32 & 19.2 \\
$\quad$ Not educated & 77 & 46.1 \\
Elementary school & 44 & 5.3 \\
Junior high school & 9 & \\
Senior high school & & \\
College/ university & & \\
\hline
\end{tabular}

Table 1 shows that majority of the respondents were not suffered from chronic energy deficiency $(73.7 \%)$, had poor knowledge $(50.9 \%)$, had no history of disease $(94.6 \%)$, majority of them were multipara $(78.4 \%)$, had low family income (94\%), and had junior high school education background (46.1\%). 
Table 2. The relationship between knowledge, education, and family support toward ANC visit

\begin{tabular}{|c|c|c|c|c|c|c|c|}
\hline & \multicolumn{4}{|c|}{ Chronic Energy Deficiency } & \multicolumn{2}{|c|}{ Total } & \multirow{3}{*}{$p$} \\
\hline & \multicolumn{2}{|c|}{ Yes } & \multicolumn{2}{|c|}{ No } & \multirow[b]{2}{*}{$n$} & \multirow[b]{2}{*}{$\%$} & \\
\hline & $\mathrm{n}$ & $\%$ & $\mathrm{n}$ & $\%$ & & & \\
\hline \multicolumn{8}{|l|}{ Knowledge } \\
\hline Good & 14 & 31.8 & 68 & 55.3 & 82 & 49.1 & 0.006 \\
\hline Poor & 30 & 68.2 & 55 & 44.7 & 85 & 50.8 & \\
\hline \multicolumn{8}{|l|}{ Disease history } \\
\hline Yes & 7 & 15.9 & 2 & 1.6 & 9 & 5.4 & 0.001 \\
\hline No & 37 & 84.1 & 121 & 98.4 & 158 & 94.6 & \\
\hline \multicolumn{8}{|l|}{ Parity } \\
\hline Primipara & 10 & 22.7 & 19 & 15.4 & 29 & 17.3 & 0.009 \\
\hline Multipara & 29 & 66 & 102 & 83 & 131 & 78.5 & \\
\hline Grande Multipara & 5 & 11.3 & 2 & 1.6 & 7 & 4.2 & \\
\hline \multicolumn{8}{|l|}{ Family income } \\
\hline High & 2 & 4.5 & 8 & 6.5 & 10 & 6 & 0.482 \\
\hline Low & 42 & 95.5 & 115 & 93.5 & 157 & 94 & \\
\hline \multicolumn{8}{|l|}{ Education } \\
\hline Not educated & 2 & 4.5 & 3 & 2.4 & 5 & 3 & 0.745 \\
\hline Elementary school & 9 & 20.5 & 23 & 18.7 & 32 & 19.1 & \\
\hline Junior high school & 19 & 43.2 & 58 & 47.1 & 77 & 46.1 & \\
\hline Senior high school & 13 & 29.5 & 31 & 25.2 & 44 & 26.4 & \\
\hline College/university & 1 & 2.3 & 8 & 6.5 & 9 & 5.4 & \\
\hline Total & 44 & 100 & 123 & 100 & 167 & 100 & \\
\hline
\end{tabular}

Table 2 shows that, out of 44 respondents who were suffered from CED, majority of them (68.2\%) had poor knowledge about nutrition during pregnancy. There was a relationship between knowledge and CED $(p=0.006)$. Out if 44 respondents who were suffered from CED, majority of them had no history of diseases. However, the bivariate analysis found that there was a significant relationship between disease history and CED $(p=0.001)$. Out of 44 respondents who were suffered from CED, majority of them were multipara $(66 \%)$. In addition, there was a significant relationship between Parity and CED $(p=0.009)$. Out of 44 respondents who were suffered from CED, majority of them $(95.5 \%)$ had low family income. However bivariate analysis found that there was no significant relationship between family income and CED ( $p=0.482)$. Out of 44 respondents who were suffered from CED, majority of them had junior high school education background (43.2\%). In addition, there was no relationship between education background and CED ( $p$ $=0.745$ ).

\section{DISCUSSION}

The knowledge possessed by women will influence decision making and will also affect her behaviour. Mothers with good knowledge regarding nutrition during pregnancy are likely to provide adequate nutrition to their babies, this is even more important when the mother enters a period of cravings, which is usually a stomach that is reluctant to enter any nutritious food, because of the feeling of nausea that is felt, it will choose food with a fresh and sour taste. Even in such conditions if a mother has good knowledge then the mother will try to meet the nutritional needs of her and her baby (Proverawati, 2009). The results of this study are in accordance with the research conducted by Sri and Suci (2011), entitled "Analysis of factors that affect chronic energy deficiency in pregnant women in the Wedi Klaten community health center". the effect of knowledge on the incidence of CED. The researcher assumes that there were still many respondents who have low knowledge because, this CED is less known because respondents have never consulted with health workers about CED and the lack of information sources so that respondents do not know about CED.

A history of illness before pregnancy can act as a starter for malnutrition as a result of decreased appetite, impaired absorption in the digestive tract or increased nutritional requirements due to disease (Novelia et al., 2020). The relationship between disease and malnutrition is a reciprocal relationship which is a causal relationship. Diseases can worsen nutritional conditions and poor nutritional conditions can facilitate diseases that are generally associated with nutritional problems, including diarrhea, tuberculosis, stomach, typhoid and DM, Muliawati (2013). The results of this study are in accordance with research conducted by Indriati et al. (2017), entitled "Factors Associated with Chronic 
Energy Deficiency Incidences in Pregnant Women at the Warung Jambu Public Health Center, Bogor City" which concluded that there was a relationship between a history of disease and chronic energy deficiency in pregnant women. The researcher assumed that respondents who have a history of disease experiencing CED because history of disease before pregnancy can act as a starter for malnutrition as a result of decreased appetite and impaired absorption in the digestive tract due to disease.

Parity or para are those who have given birth to a term baby (Manuaba, 1998). Several terms related to parity are (1) Nullipara is a woman who has never given birth to a viable baby, (2) Primapara is a woman who has given birth to a live baby for the first time, (3) Multipara is a woman who has given birth to a viable baby several times (up to 5 times), and (4) Grandemultipara are women who have given birth to 6 or more live or dead babies (Lubis, 2013). The results of this study are in accordance with research conducted by Laila Rahmi (2016), entitled "Factors Associated with Chronic Energy Deficiency in Pregnant Women at Belimbing Padang Health Center." parity has relationship with CED in pregnant women. High parity can lead to circumstances affecting the optimization of the mother and fetus in the pregnancy they are facing, thus results in CED.

Food consumption behavior is a reflection of the interaction between economic factors and socio-cultural factors. Economic factors relate to the level of income and give birth to the purchasing power of a person or group of people if the income level is balanced with the number of family members who are the burden. The size of a family and the composition of a family with the level of family income are associated with the quality and quantity of the diet that prevails in the family. Family income in this case is all income or requests from all family members obtained in the form of wages or salaries, BPS (2008). The results of this study are in accordance with the research conducted by Sri and Suci (2011), entitled "Analysis of factors that influence chronic energy deficiency in pregnant women in the area of Wedi Klaten Health Centre" which found that there was no relationship between income and the incidence of CED.

The formal education of housewives often has a positive association with the development of food consumption patterns in the family. Several studies show that if the education level of the mother increases, the knowledge of nutrition and nutrition practice improves. Efforts to choose foods that have nutritional value are increasing, housewives who have nutritional knowledge will choose foods that are more nutritious than those that are less nutritious. Mother's education in this study was divided into levels from SD, SMP, SMA/MA, and S1, according to Siti (2013). The results of this study was in accordance with research conducted by Khadija et al., (2018), entitled "The Relationship of Family Income and Mother's Education Level with Chronic Energy Deficiency Incidence in Pregnant Women in the Puuwatu Health Center Work Area, Kendari City, Southeast Sulawesi Province in 2018 The results of statistical analysis using the Chi Square test with $p$ value $=0.418$, it can be concluded that there was no relationship between education and the incidence of Chronic Energy Deficiency in pregnant women. The health workers especially midwife need to put attention about the knowledge of pregnant women regarding nutrition during pregnancy. A health education should be provided in antenatal care. The government also need to provide the additional nutrition for pregnant women as the effort to prevent the chronic energy deficiency.

\section{CONCLUSION}

The results of the study showed that the majority of pregnant women were not suffered from CED was $(73.7 \%)$, had poor knowledge was (50.9\%), did not have a history of disease was (94.6\%), multipara was 131 people $(78.4 \%)$, had low family income was (94\%), had junior high school education was (46.1\%). There was a significant relationship between knowledge, disease history and parity with CED. There was no significant relationship between family income and education with CED. It is hoped that the Gunung Kaler Health Center provide counseling related to CED with a variety of interesting methods for pregnant women. Future researchers are expected to be able to analyze other factors that influence the CED case.

\section{ACKNOWLEDGEMENT}

The authors thanks to Universitas Nasional who provided partial funding for publication. 


\section{REFERENCES}

Dinas Kesehatan Provinsi Banten. (2016). Data Kematian Ibu.

Hamzah, D. F. (2017). Analisis Faktor Yang Memengaruhi Kejadian Kekurangan Energi Kronis (Kek) Pada Ibu Hamil Di Wilayah Kerja Puskesmas Langsa Kota Kota Langsa Provinsi Aceh Tahun 2016. Jumantik (Jurnal Ilmiah Penelitian Kesehatan), 2(2), $1-11$.

Hasanah, D. N., Febrianti, F., \& Minsarnawati, M. (2013). Kebiasaan Makan menjadi Salah Satu Penyebab Kekurangan Energi Kronis (KEK) pada Ibu Hamil di Poli Kebidanan RSI\&A Lestari Cirendeu Tangerang Selatan. Indonesian Journal of Reproductive Health, 4(2), 106703.

Kementerian Kesehatan Rl. (2014). Pusat Data Dan Informasi Kementerian Kesehatan Rl. Retrieved from http:/l www.depkes.go.idresourcesdownload pusdatinin fodatin infodatin-ibu.pdf (27 April 2019).

Kementerian Kesehatan RI. (2016). Profile Kesehatan Kabpaten Tangerang, Retrieved from http://www.Depkes.go.id/resources/download/LAKIP\%202018/LKj\%20Unit\%20Utama/1.\%20Kesmas. (28 April 2019).

Lubis, L.N. (2013). Wanita Dan Perkembangan Reproduksinya Ditinjau Dari Aspek Fisik Dan Psikologinya, Perpustakaan Nasional,

Novelia, S., Dewi, A., Melinasari, S., Widowati, R., \& Carolin, B. T. (2020). Iron and Orange Extract on Hemoglobin among Anemic Pregnant Women in Nusa Tenggara Barat in 2018. Asian Community Health Nursing Research, 2(1), 8-12. Jakarta, 50.

Petrika, Y., Hadi, H., \& Nurdiati, D. S. (2016). Tingkat asupan energi dan ketersediaan pangan berhubungan dengan risiko kekurangan energi kronik (KEK) pada ibu hamil. Jurnal Gizi dan Dietetik Indonesia (IndonesiaL Journal of Nutrition and Dietetics), 2(3), 140-149.

Proverawati, A, \& Asfuah, S, (2009). Gizi Untuk Kebidanan, Nuha Medika, Yogyakarta

Rahmaniar, A., Taslim, N. A., \& Bahar, B. (2013). Faktor-Faktor yang Berhubungan dengan Kekurangan Energi Kronis Pada Ibu Hamil di Tampa Padang

Rahmi, L. (2016). Gambaran Berat Plasenta Terhadap Berat Lahir Bayi. Jurnal Kesehatan Medika Saintika, 7(1).

Simbolon, D., Jumiyati \& Rahmadi, A. (2018). Pencegahan dan Penanggulangan Kurang Energi Kronik (KEK) Dan Anemia Pada Ibu Hamil. CV Budi Utama, Yogyakarta 